\title{
Deep resequencing of the voltage-gated potassium channel subunit KCNE3 gene in chronic tinnitus
}

\author{
Philipp G Sand ${ }^{1}$, Berthold Langguth ${ }^{1}$ and Tobias Kleinjung ${ }^{2,3^{*}}$
}

\begin{abstract}
Membrane-stabilizing drugs have long been used for the treatment of chronic tinnitus, suggesting an underlying disturbance of sensory excitability due to changes in ion conductance. The present study addresses the potassium channel subunit gene KCNE3 as a potential candidate for tinnitus susceptibility. 288 Caucasian outpatients with a diagnosis of chronic tinnitus were systematically screened for mutations in the KCNE3 open reading frame and in the adjacent region by direct sequencing. Allele frequencies were determined for 11 known variants of which two $(\mathrm{F} 66 \mathrm{~F}$ and $\mathrm{R} 83 \mathrm{H})$ were polymorphic but were not associated with the disorder. No novel variants were identified and only three carriers of R83H were noted. However, owing to a lack of power, our study can neither rule out effects of KCNE3 on the risk for developing chronic tinnitus, nor can it exclude a role in predicting the severity of tinnitus. More extensive investigations are invited, including tests for possible effects of variation in this ion channel protein on the response to treatment.
\end{abstract}

\section{Findings}

Tinnitus is an unpleasant sensation often described as 'ringing in the ears' that may manifest in a variety of settings, e.g. after acoustic trauma, as a side effect of medication, or spontaeously [1]. Epidemiological studies suggest that close to $15 \%$ of the adult population may be affected to varying degrees [2]. In severe cases, patients develop a chronic course of illness marked by sleep disturbances, depressed mood, increased muscle tension and loss of attention, or other comorbidities [3]. While the underlying biological mechanisms are still incompletely understood, early research into the pharmacological treatment of tinnitus has emphasized a role for cellular ion regulation and transport [4]. Interest in the disruption of ion conductance in the inner ear has been renewed following recent discoveries in other heritable pathologies of auditory perception. Specifically, dysfunctional $\mathrm{K}^{+}$-extruding cells of the stria vascularis are known to interfere with potassium homeostasis and the endocochlear potential in Jervell and Lange-Nielsen Syndrome (JLNS) types 1 and 2 [5,6], in DNFA2 [7],

\footnotetext{
* Correspondence: tobias.kleinjung@usz.ch

${ }^{2}$ Department of Otorhinolaryngology, University of Regensburg Franz-Josef-

Strauss-Allee 11, 93053 Regensburg, Germany

Full list of author information is available at the end of the article
}

and in EAST syndrome [8], among others. Variants in the genes encoding voltage-gated potassium channel proteins KCNQ1, KCNQ4, and KCNE1 have also been proposed as candidate risk modifiers in more common disorders of the auditory pathway, e.g. in Menière's disease [9], in noise-induced hearing loss [10,11], in agerelated hearing loss [12], and in chronic tinnitus [13].

A further candidate gene, encoding the potassium channel $\AA$ subunit KCNE3/MIRP2, has been adressed in Menière's disease [9]. Like KCNE1, KCNE3 is expressed in the mammalian inner ear [14] and brain $[15,16]$. Both proteins interact to regulate trafficking, surface expression, and activation of another potassium channel, $\mathrm{KCNH} 3$, in the cortex and in other parts of the central nervous system [17]. So far, a limited number of investigations has addressed sequence variation in KCNE3 which maps to chromosome 11q13-14, a linkage hotspot for autosomal recessive, non-syndromal hearing impairment [18]. In view of the frequent association of tinnitus and hearing impairment [19], and of its cooccurence with Menière's disease [20], we hypothesized that tinnitus may be part of the phenotypic spectrum that is caused by KCNE3 variants.

In 288 outpatients ( 202 men and 86 women, age 50.1 \pm 12.6 yrs, mean \pm SD) consulting for chronic tinnitus 
(minimum duration of 6 months), the diagnosis was confirmed by a detailed neurootological examination including otoscopy, stapedius reflexes, middle ear pressure measurements, pure tone audiometry, tinnitus pitch and loudness matches. For the present study, those patients with a history of vestibular schwannoma, Menière's disease, or pathological middle ear conditions were excluded. The remaining subjects suffered from primary tinnitus and family histories were available in 139 subjects. Of these, 38\% reported at least one firstdegree relative affected by tinnitus. Tinnitus severity was assessed by the Tinnitus Questionnnaire (TQ) [21] in 283 patients $(98.3 \%)$. All participating subjects were Caucasians and most originated from the Upper Palatinate region of Bavaria. Nine external control populations, matched for Caucasian background, served to test for association of KCNE3 variants with tinnitus susceptibility ([22-25], PharmGKB, dbSNP, HapMap-CEU and HapMap-TSI populations). The level of statistical significance was set at $p<0.05$.

Genomic DNA was extracted from lymphocytes using standard pocedures prior to amplification of the KCNE3 coding region by PCR. Briefly, a 748 bp amplicon was generated using the following oligomers: 5 '-CCA TCC CCT CTC TCT TTT CT-3' (forward) and 5'-CCA GAG CAT CTT CCT GTC TC-3' (reverse). PCR products were purified for Sanger sequencing and for the identification of variants against the human genome reference (Genome Reference Consortium Build 37, February 2009 release). Multiple sequence alignments were conducted with DNA Dynamo 1.0 (Blue Tractor Software, UK). STATA 8.0 (Stata Corporation, College Station, TX, USA) was used for statistical analyses. KCNE3 allele frequencies from reference populations were compared to the present data using Fisher's exact test. All $p$ values are uncorrected for multiple testing.

For assessing the functionality of coding variants observed in our sample, evolutionary conservation was assessed with a phylogenetic hidden Markov modelbased method, PhastCons, that describes the process of DNA substitution at each site in a genome and the way this process changes from one site to the next [26]. Genomic sequences from 46 placental mammals were aligned to the human reference delimited by forward and reverse primers using a Threaded Blockset Aligner [27] as implemented in the conservation track of the UCSC Genome Browser [28]. Linkage disequilibrium and conformity with Hardy-Weinberg equilibrium was measured with HaploView 4.2. [29] and PS V2.1.15 [30] was used for power simulations.

We confirmed two known coding variants with observed heterozygosities of 0.215 (F66F) and 0.01 $(\mathrm{R} 83 \mathrm{H})$, and featuring genotype distributions that conformed to the Hardy-Weinberg equilibrium ( $p>0.79$,
Table 1). Five additional KCNE3 variants listed in dbSNP were absent from our sample (rs34604640, rs17215444, rs17221826, rs17221833, rs11822977). Four previously reported KCNE3 mutations were also absent: T4A [31], V17M [32], R53H [33], and R99H [31,34]. No novel sequence variants were observed. When minor allele frequencies for F66F and R83H were compared to reference frequencies from nine Caucasian control populations, no significant difference was noted $(\mathrm{p}>$ 0.22 , Table 2). Power simulations, based on the entire sample of patients diagnosed with chronic tinnitus and on published control data, indicated that we should expect a statistical power of $>80 \%$ to detect a susceptibility factor with an allelic relative risk of $>1.56$ for the F66F variant, and of $>3.27$ for the $\mathrm{R} 83 \mathrm{H}$ amino acid exchange. The number of tinnitus cases needed to reach this power was estimated at 2,707 and 65,083, respectively.

We next examined whether KCNE3 variants could serve as predictors of tinnitus severity in the population under study. Overall, TQ scores averaged $40.0 \pm 18.4$ (mean $\pm \mathrm{SD})$ out of 84 points $(\mathrm{N}=283)$. By this measure, tinnitus was rated mild ( 0 to 30 points) in 94 subjects $(33.2 \%)$, moderate (31 to 46 points) in 84 subjects (29.7\%), severe (47 to 59 points) in 55 subjects (19.4\%), and extreme (60 to 84 points) in 50 subjects (17.7\%). There was no significant difference in mean TQ scores between carriers and non-carriers of the minor alleles at either of the two confirmed polymorphic KCNE3 nucleotides ( $p>0.22$, data not shown). As we encountered only three carriers of the rare missense variant $\mathrm{R} 83 \mathrm{H}\left(\mathrm{f}_{\mathrm{HIS} 83}=0.005\right)$, the impact of this substitution on tinnitus severity could not be fully judged. However, neither of the two variants is expected to be inert by comparative genomic analysis (Figure 1). More detailed examinations, e.g. by heterologous expression, are required to understand the effects of F66F and $\mathrm{R} 83 \mathrm{H}$ on potassium signaling.

The above evidence illustrates that the KCNE3 coding region is remarkably well conserved in a moderately sized population with chronic tinnitus, evoking similar findings in other pathologies $[35,36]$. The power of the present study is, however, inadequate to rule out an association with tinnitus. Considering the phenotypic overlap of tinnitus and Menière's disease, the present negative findings diverge from the significant association of KCNE3 with Menière's disease claimed by Doi et al. [9], but this may be due to methodological issues [22]. The possibility remains that among our external control subjects classified as "healthy», some may have experienced mild forms of tinnitus. Future studies employing a matched set of cases and controls should put this into perspective. Moreover, we gave priority to the gene's coding region and did not adress regulatory variation, or 
Table 1 Observed allele frequencies for the $K C N E 3$ sequence screened in subjects with chronic tinnitus (2N = 576).

\begin{tabular}{|c|c|c|c|c|}
\hline SNP (dbSNP ID) & $\begin{array}{c}\text { chr11 } \\
\text { position }\end{array}$ & $\begin{array}{l}\text { variant amino } \\
\text { acid }\end{array}$ & $\begin{array}{l}\text { minor allele frequency in chronic } \\
\text { tinnitus }\end{array}$ & $\begin{array}{l}\text { homozygous/heterozygous carriers of the minor } \\
\text { allele }\left(p_{\text {HWE }}\right)\end{array}$ \\
\hline g.15,002T>C & $74,168,599$ & T4A & 0.000 & - \\
\hline g. $15,041 \mathrm{G}>\mathrm{A}$ & $74,168,560$ & V17M & 0.000 & - \\
\hline $\begin{array}{l}.15,108 C>G \\
(\mathrm{rs} 34604640)\end{array}$ & $74,168,493$ & P39R & 0.000 & - \\
\hline $\begin{array}{l}.15,131 C>G \\
\text { (rs17215444) }\end{array}$ & $74,168,470$ & R47G & 0.000 & - \\
\hline g. $15,150 \mathrm{G}>\mathrm{A}$ & $74,168,451$ & $\mathrm{R} 53 \mathrm{H}$ & 0.000 & - \\
\hline $\begin{array}{l}\text { g.15,190T>C } \\
\text { (rs2270676) }\end{array}$ & $74,168,411$ & F66F & 0.125 & $5 / 62(0.788)$ \\
\hline $\begin{array}{l}\text { g.15,220C>T } \\
\text { (rs17221826) }\end{array}$ & $74,168,381$ & 1761 & 0.000 & - \\
\hline $\begin{array}{l}\text { g.15,240G>A } \\
\text { (rs17215437) }\end{array}$ & $74,168,361$ & R83H & 0.005 & $0 / 3(0.930)$ \\
\hline $\begin{array}{l}\text { g.15,255G>A } \\
\text { (rs17221833) }\end{array}$ & $74,168,346$ & $\mathrm{R} 88 \mathrm{H}$ & 0.000 & - \\
\hline g.15,288G>A & $74,168,313$ & $\mathrm{R} 99 \mathrm{H}$ & 0.000 & - \\
\hline $\begin{array}{l}\text { g.15,321C>T } \\
(\mathrm{rs} 11822977)\end{array}$ & $74,168,280$ & - & 0.000 & - \\
\hline
\end{tabular}

Numbering of SNPs refers to RefSeq NG 0118331.1. Polymorphic variants in bold.

variation in the remaining noncoding regions. Results of the present screening are therefore preliminary with regard to a proposed functionality of $K C N E 3$ in tinnitus.

A complex interplay of multimeric potassium channelforming proteins in auditory perception calls for followup examinations of interacting molecules that control the excitability of sensory neurons, including structures that are targeted by anti-tinnitus drugs. For lidocaine, these candidates comprise KCNA1 and $\mathrm{KCNC} 1$, plus $\mathrm{KCNH} 2[37,38]$, which has also been implicated in phenytoin effects [39].

In view of the limited power of our pilot study and the need to assesss promotor variation, more research is invited to address KCNE3 impact on the perception of phantom auditory sensations. Finally, variation relating to channel structures that interact with $K C N E 3$ may

Table 2 Reference allele frequencies and measures of association for g.15,190T>C (rs2270676 encoding F66F) and g.15,240G > A (rs17215437 encoding R83H), based on data from 474 and 1,140 Caucasian controls, respectively.

\begin{tabular}{|c|c|c|c|c|c|}
\hline Healthy controls ( $\left.\mathrm{N}_{\text {unrelated }}\right)$ & study & $\begin{array}{l}\text { g.15,190T>C } \\
\text { (F66F) } \\
\text { frequency in } \\
\text { controls }\end{array}$ & $\begin{array}{l}\text { g.15,190T }>\text { C } \\
\text { (F66F) } \\
\text { controls vs. } \\
\text { tinnitus patients }\end{array}$ & $\begin{array}{l}\text { g.15,240G>A } \\
\text { (R83H) } \\
\text { frequency in } \\
\text { controls }\end{array}$ & $\begin{array}{l}\text { g.15,240G }>\text { A } \\
\text { (R83H) } \\
\text { controls } \\
\text { vs. } \\
\text { tinnitus } \\
\text { patients }\end{array}$ \\
\hline "White" Brazilian (40) & [23] & - & - & 0.000 & n.s. \\
\hline French (506) & [24] & - & - & 0.008 & n.s. \\
\hline German (321) & [25] & - & - & 0.005 & n.s. \\
\hline U.S., European descent (180) & [22] & 0.117 & n.s.* & 0.003 & n.s. \\
\hline Caucasian (48) & $\begin{array}{l}\text { PharmGKB } \\
\text { PS203664 }\end{array}$ & 0.083 & n.s. & 0.010 & n.s. \\
\hline Caucasian (45) & $\begin{array}{c}\mathrm{dbSNP} \\
\mathrm{ss} 65626119 \\
\end{array}$ & 0.089 & n.s. & - & - \\
\hline Caucasian (45) & $\begin{array}{c}\mathrm{dbSNP} \\
\text { ss65626296 }\end{array}$ & - & - & 0.011 & n.s. \\
\hline $\begin{array}{l}\text { Utah residents with Northern and Western European } \\
\text { ancestry from the CEPH collection (113) }\end{array}$ & $\begin{array}{l}\text { HapMap-CEU } \\
\text { ss38798969 }\end{array}$ & 0.093 & n.s. & - & - \\
\hline Tuscans in Italy (88) & $\begin{array}{l}\text { HapMap-TSI } \\
\text { ss38798969 }\end{array}$ & 0.108 & n.s. & - & - \\
\hline
\end{tabular}

dbSNP data refer to NCBI build 132, HapMap data refer to two out of the 11 populations in phase 3.

${ }^{*}$ n.s. $=$ not significant 


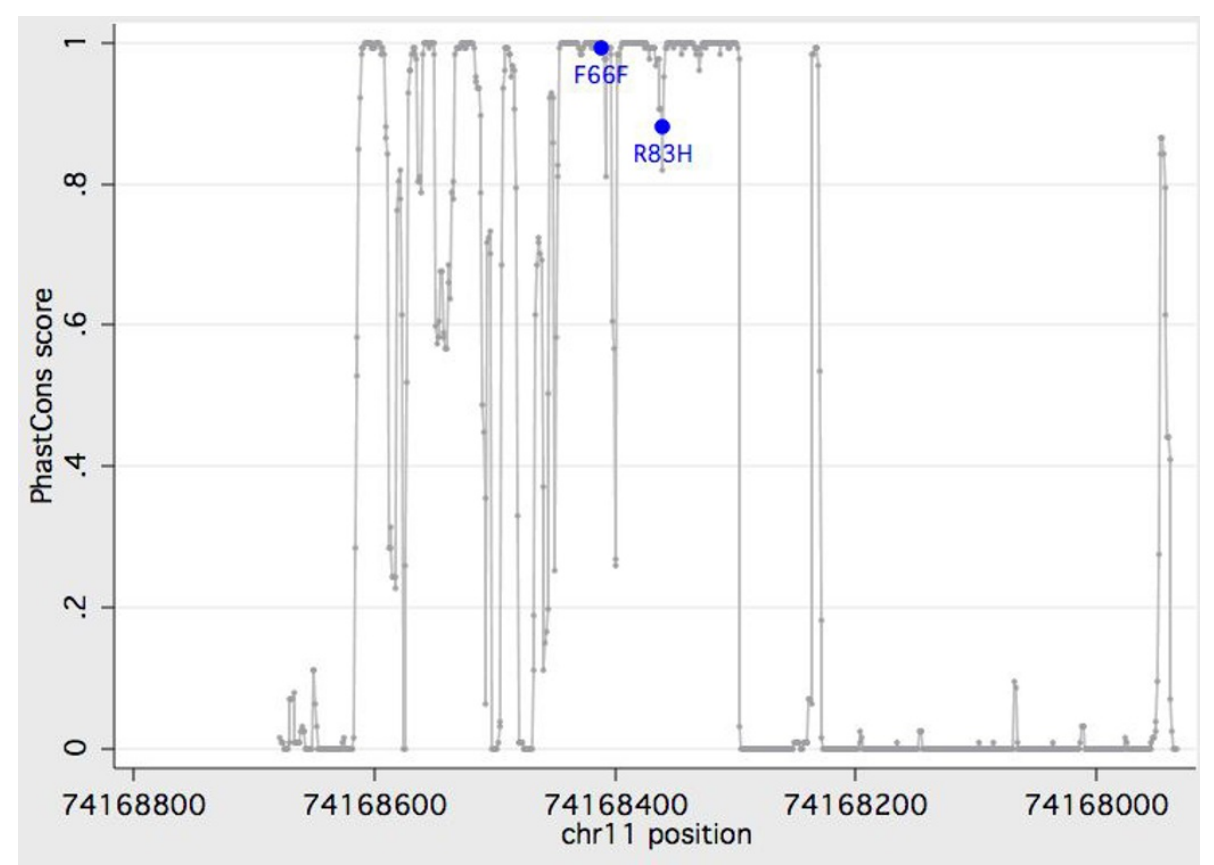

Figure 1 Evolutionary conservation of the KCNE3 amplicon under study. The degree of conservation (PhastCons score) is plotted against the physical position based on genomic sequence information from 46 placental mammals. Both g.15,190T>C (rs2270676 encoding F66F) and g.15,240G > A (rs 17215437 encoding R83H) map to a highly conserved part of the open reading frame. The ORF is delimited by positions $74,168,608$ and 74,168,296 on the February 2009 Homo sapiens high coverage assembly (Hg19) from the Genome Reference Consortium (GRCh37).

also help in predicting the response to membrane-stabilizing drugs. KCNE3 encodes a beta transmembrane subunit that assembles with several alpha subunits to modify gating and pharmacological sensitivity. It is highly likely that a mutation in KCNE3 alone may not be indicative of tinnitus, but when mutations are present in both KCNE3 and the channel with which it is interacting (e.g. KCNQ1) the biophysical properties of the channel complex are significantly altered.

\section{Acknowledgements}

The authors gratefully acknowledge technical assistance by M. Domani.

\section{Author details}

'Department of Psychiatry, University of Regensburg Universitätsstr. 84, 93042 Regensburg, Germany. ${ }^{2}$ Department of Otorhinolaryngology, University of Regensburg Franz-Josef-Strauss-Allee 11, 93053 Regensburg, Germany. ${ }^{3}$ Department of Otorhinolaryngology, University of Zurich, Frauenklinikstrasse 24, 8091 Zurich, Switzerland.

\section{Authors' contributions}

Authors PGS, BL and TK acquired, analysed and interpreted the data. PGS designed the study and drafted the original manuscript. All authors revised the manuscript for important intellectual content and provided final approval of the version to be published.

\section{Competing interests}

The authors declare that they have no competing interests.

Received: 23 February 2011 Accepted: 7 September 2011 Published: 7 September 2011

\section{References}

1. Moller AR: Tinnitus: presence and future. Prog Brain Res 2007, 166:3-16.

2. Shargorodsky J, Curhan GC, Farwell WR: Prevalence and characteristics of tinnitus among US adults. Am J Med 2010, 123:711-718.

3. Quantification of the burden of disease for tinnitus caused by community noise. Background paper. [http://www.chuq.qc.ca/oms/pdf/ TinnitusBackgroundPaper2005.pdf].

4. Bárány R: Die Beeinflussung des Ohrensausens durch intravenös injizierte Lokalanästhetika. Acta Oto-Laryngologica 1936, 23:201-203.

5. Neyroud N, Tesson F, Denjoy I, Leibovici M, Donger C, Barhanin J, Faure S, Gary F, Coumel P, Petit C, et al: A novel mutation in the potassium channel gene KVLQT1 causes the Jervell and Lange-Nielsen cardioauditory syndrome. Nat Genet 1997, 15:186-189.

6. Tyson J, Tranebjaerg L, Bellman S, Wren C, Taylor JF, Bathen J, Aslaksen B, Sorland SJ, Lund O, Malcolm S, et al: IsK and KvLQT1: mutation in either of the two subunits of the slow component of the delayed rectifier potassium channel can cause Jervell and Lange-Nielsen syndrome. Hum Mol Genet 1997, 6:2179-2185.

7. Coucke PJ, Van Hauwe P, Kelley PM, Kunst H, Schatteman I, Van Velzen D, Meyers J, Ensink RJ, Verstreken M, Declau F, et al: Mutations in the KCNQ4 gene are responsible for autosomal dominant deafness in four DFNA2 families. Hum Mol Genet 1999, 8:1321-1328.

8. Sala-Rabanal M, Kucheryavykh LY, Skatchkov SN, Eaton MJ, Nichols CG: Molecular mechanisms of EAST/SeSAME syndrome mutations in Kir4.1 (KCNJ10). J Biol Chem 2010, 285:36040-36048.

9. Doi K, Sato T, Kuramasu T, Hibino H, Kitahara T, Horii A, Matsushiro N, Fuse Y, Kubo T: Meniere's disease is associated with single nucleotide polymorphisms in the human potassium channel genes, KCNE1 and KCNE3. ORL J Otorhinolaryngol Relat Spec 2005, 67:289-293.

10. Van Laer L, Carlsson PI, Ottschytsch N, Bondeson ML, Konings A, Vandevelde A, Dieltjens N, Fransen E, Snyders D, Borg E, et al: The contribution of genes involved in potassium-recycling in the inner ear to noise-induced hearing loss. Hum Mutat 2006, 27:786-795.

11. Pawelczyk M, Van Laer L, Fransen E, Rajkowska E, Konings A, Carlsson PI, Borg E, Van Camp G, Sliwinska-Kowalska M: Analysis of gene 
polymorphisms associated with $\mathrm{K}$ ion circulation in the inner ear of patients susceptible and resistant to noise-induced hearing loss. Ann Hum Genet 2009, 73:411-421.

12. Van Eyken E, Van Laer L, Fransen E, Topsakal V, Lemkens N, Laureys W, Nelissen N, Vandevelde A, Wienker T, Van De Heyning P, Van Camp G: KCNQ4: a gene for age-related hearing impairment? Hum Mutat 2006, 27:1007-1016.

13. Sand P, Luettich A, Kleinjung T, Langguth B: An examination of kcne1 mutations and common variants in chronic tinnitus. Genes 2010, 1:23-27.

14. de Castro MP, Aranega A, Franco D: Protein distribution of Kcnq1, Kcnh2, and Kcne3 potassium channel subunits during mouse embryonic development. Anat Rec A Discov Mol Cell Evol Biol 2006, 288:304-315.

15. Abbott GW, Butler MH, Bendahhou S, Dalakas MC, Ptacek L, Goldstein SA: MiRP2 forms potassium channels in skeletal muscle with Kv3.4 and is associated with periodic paralysis. Cell 2001, 104:217-231.

16. McCrossan ZA, Lewis A, Panaghie G, Jordan PN, Christini DJ, Lerner DJ, Abbott GW: MinK-related peptide 2 modulates Kv2.1 and Kv3.1 potassium channels in mammalian brain. J Neurosci 2003, 23:8077-8091.

17. Clancy SM, Chen B, Bertaso F, Mamet J, Jegla T: KCNE1 and KCNE3 betasubunits regulate membrane surface expression of $\mathrm{Kv} 12.2 \mathrm{~K}(+)$ channels in vitro and form a tripartite complex in vivo. PLoS One 2009, 4:e6330

18. Tili A, Masmoudi S, Dhouib H, Bouaziz S, Rebeh IB, Chouchen J, Turki K, Benzina Z, Charfedine I, Drira M, Ayadi H: Localization of a novel autosomal recessive non-syndromic hearing impairment locus DFNB63 to chromosome 11q13.3-q13.4. Ann Hum Genet 2007, 71:271-275.

19. Axelsson A, Sandh A: Tinnitus in noise-induced hearing loss. Br J Audiol 1985, 19:271-276.

20. Hamid MA: Meniere's disease. Pract Neurol 2009, 9:157-162.

21. Goebel G, Hiller W: [The tinnitus questionnaire. A standard instrument for grading the degree of tinnitus. Results of a multicenter study with the tinnitus questionnaire]. HNO 1994, 42:166-172.

22. Campbell CA, Della Santina CC, Meyer NC, Smith NB, Myrie OA, Stone EM, Fukushima K, Califano J, Carey JP, Hansen MR, et al: Polymorphisms in KCNE1 or KCNE3 are not associated with Meniere disease in the Caucasian population. Am J Med Genet A 2010, 152A:67-74.

23. Dias Da Silva MR, Cerutti JM, Arnaldi LA, Maciel RM: A mutation in the KCNE3 potassium channel gene is associated with susceptibility to thyrotoxic hypokalemic periodic paralysis. J Clin Endocrinol Metab 2002, 87:4881-4884

24. Sternberg D, Tabti N, Fournier E, Hainque B, Fontaine B: Lack of association of the potassium channel-associated peptide MiRP2-R83H variant with periodic paralysis. Neurology 2003, 61:857-859.

25. Jurkat-Rott K, Lehmann-Horn F: Periodic paralysis mutation MiRP2-R83H in controls: Interpretations and general recommendation. Neurology 2004, 62:1012-1015.

26. Siepel A, Bejerano G, Pedersen JS, Hinrichs AS, Hou M, Rosenbloom K, Clawson H, Spieth J, Hillier LW, Richards S, et al: Evolutionarily conserved elements in vertebrate, insect, worm, and yeast genomes. Genome Res 2005, 15:1034-1050.

27. Blanchette M, Kent WJ, Riemer C, Elnitski L, Smit AF, Roskin KM, Baertsch R, Rosenbloom K, Clawson H, Green ED, et al: Aligning multiple genomic sequences with the threaded blockset aligner. Genome Res 2004, 14:708-715.

28. Rhead B, Karolchik D, Kuhn RM, Hinrichs AS, Zweig AS, Fuijta PA, Diekhans M, Smith KE, Rosenbloom KR, Raney BJ, et al: The UCSC Genome Browser database: update 2010. Nucleic Acids Res 2010, 38:D613-619.

29. Barrett JC, Fry B, Maller J, Daly MJ: Haploview: analysis and visualization of LD and haplotype maps. Bioinformatics 2005, 21:263-265.

30. Dupont WD, Plummer WD Jr: Power and sample size calculations. A review and computer program. Control Clin Trials 1990, 11:116-128.

31. Ohno S, Toyoda F, Zankov DP, Yoshida H, Makiyama T, Tsuji K, Honda T, Obayashi K, Ueyama H, Shimizu W, et al: Novel KCNE3 mutation reduces repolarizing potassium current and associated with long QT syndrome. Hum Mutat 2009, 30:557-563.

32. Lundby A, Ravn LS, Svendsen JH, Hauns S, Olesen SP, Schmitt N: KCNE3 mutation V17M identified in a patient with lone atrial fibrillation. Cell Physiol Biochem 2008, 21:47-54

33. Zhang DF, Liang B, Lin J, Liu B, Zhou QS, Yang YQ: [KCNE3 R53H substitution in familial atrial fibrillation]. Chin Med J (Engl) 2005, 118:1735-1738.
34. Delpon E, Cordeiro JM, Nunez L, Thomsen PE, Guerchicoff A, Pollevick GD, Wu Y, Kanters JK, Larsen CT, Hofman-Bang J, et al: Functional effects of KCNE3 mutation and its role in the development of Brugada syndrome. Circ Arrhythm Electrophysiol 2008, 1:209-218.

35. Miller TM, Dias da Silva MR, Miller HA, Kwiecinski H, Mendell JR, Tawil R, McManis P, Griggs RC, Angelini C, Servidei S, et al: Correlating phenotype and genotype in the periodic paralyses. Neurology 2004, 63:1647-1655.

36. Wang W, Jiang L, Ye L, Zhu N, Su T, Guan L, Li X, Ning G: Mutation screening in Chinese hypokalemic periodic paralysis patients. Mol Genet Metab 2006, 87:359-363.

37. Trellakis S, Benzenberg D, Urban BW, Friederich P: Differential lidocaine sensitivity of human voltage-gated potassium channels relevant to the auditory system. Otol Neurotol 2006, 27:117-123.

38. Lin MT, Wu MH, Chang CC, Chiu SN, Theriault O, Huang H, Christe G, Ficker E, Chahine M: In utero onset of long QT syndrome with atrioventricular block and spontaneous or lidocaine-induced ventricular tachycardia: compound effects of hERG pore region mutation and SCN5A N-terminus variant. Heart Rhythm 2008, 5:1567-1574.

39. Danielsson BR, Lansdell K, Patmore L, Tomson T: Phenytoin and phenobarbital inhibit human HERG potassium channels. Epilepsy Res 2003, 55:147-157.

doi:10.1186/1744-9081-7-39

Cite this article as: Sand et al:: Deep resequencing of the voltage-gated potassium channel subunit KCNE3 gene in chronic tinnitus. Behavioral and Brain Functions 2011 7:39.

\section{Submit your next manuscript to BioMed Central and take full advantage of:}

- Convenient online submission

- Thorough peer review

- No space constraints or color figure charges

- Immediate publication on acceptance

- Inclusion in PubMed, CAS, Scopus and Google Scholar

- Research which is freely available for redistribution 